\title{
LANDSCAPE AS THE OBJECT OF INVESTIGATION OF VARIOUS DISCIPLINES
}

The term "landscape" functions in various disciplines of science. It is primarily used by geographers and biologists, but it can also be found in, for instance, architecture and geochemistry. At the same time, the word "landscape" is used in common speech to denote the natural scenery (rural and industrial landscape, winter and summer landscape, ugly and nice one, etc.).

In physical geography, the term landscape is ambigous. For instance, in Poland landscape is used in the meaning of a geocomplex perceived in its typological aspects and hierarchically classified. At the same time, it can also denote the scenery of the Earth's surface. It should be added, however, that the term is used as a general notion, thus, landscape is the object of study in landscape geography, as soil is research object of soil science or climate of climatology. By some, landscape is also understood as a synonym of physiogeographical region.

Most frequently, physical geographers use the concept of natural landscape, i.e. landscape that is delimited based on its natural characteristics. Natural landscapes are also distinguished within areas that have been considerably transformed by man, it means that natural landscape should not be identified with primeval landscapes, unchanged by human activity. Troll (1950) distinguished natural landscape (Naturliche Landschaft), delimited on the basis of natural criteria, and nature landscape (Naturlandschaft) relating to areas unchanged by human activity. Troll contrasted them with cultural landscape (Kulturlandschaft) which were developed as a result of strong anthropogenic impact on the natural environment.

All this implies that physical geographers, in distinguishing landscapes, primarily take into account the natural factors, although with an emphasis on landscape's man made features. Therefore, man is not treated as an element of the natural system, which is the main difference between the geographic view and the landscape - ecological one. It should be observed, however, that some physical geographers have studied anthropogenic landscapes where the human factor has been seen as the dominant one.

Geochemistry of landscape primarily studies chemical properties of individual components of natural systems and migrations of specific chemical 
substances in the landscape. Unlike geological geochemistry, geochemistry of landscape deals with chemical transformations occurring at a temperature lower than $100^{\circ}$ Celsius, in the presence of oxygen, under normal atmospheric pressure and with the participation of live organisms. The course of chemical processes depends on the circulation of water and the income of solar energy. Another important factor determining the course of phenomena studied by landscape geochemistry is the production of organic matter.

In the concept of geochemical landscapes, analysis of the subordination of neighbouring units is of crucial importance. The following types of landscapes are distinguished: autonomous (eluvial), eluvial-accumulative, accumulative-eluvial, trans-eluvial, superaquatic and subaquatic.

The classification of geochemical landscapes is based on the quantitative and qualitative analysis of the migration of elements in water and atmosphere, taking into account the biological circulation. The application of landscape geochemistry methods allows for more objectivity in the research process since geochemical properties are measurable, unlike the majority of characteristics investigated in the study of natural systems.

Geobotanic landscape as perceived by the majority of authors is a real, spatial, dynamic, structural and functional system at a supra-ecosystemic level of biosphere organisation. The elements of landscape are ecosystems interconnected with regular mutual relationships and dependence on common habitat conditions. Landscape is treated as one of the many levels of hierarchic organisation of the biosphere.

The manner of distinguishing vegetation landscapes is largely affected by the system of community classification. In the countries where the floristic classification of communities and the concept of relative discontinuity of plant cover is popular, an analysis of spatial mosaics provides the basis for the distinguishing of hierarchical units. Contrarily, where the so-called ecological classification of vegetation or methods of its ordination or gradient analysis are preferred, most frequently we deal with spatial units identification on the basis of catena analysis.

In animal ecology (and in general ecology), landscape formulations are still at the preliminary stage of research. Several directions of research could be mentioned. One is the application of ecological indicators in the diagnosis of the condition and dynamics of landscape, while another treats landscape as an area of interaction between local animal populations. Analysis of the so-called animal territorialism can be seen as a development of this view.

Recently, research has focused on the identification and description of the integrating role performed in landscape by those animal populations which simultaneously occupy two or more territories.

As we can see, zoological and general ecology landscape study focuses on its functional aspects rather than on the structural differentiation of space.

Landscape is also present in the terminology of architecture. According to Bogdanowski's definition (1990), landscape architecture is an art of seeing and shaping space in the landscape dimension and landscape is treated as 
the physiognomy of the environment and a formal expression of its content. The division of the given area into the so-called landscape- architecture units is based on the existing landforms, plant cover and housing, and on historic features reflecting the transformations and relations within the landscape. The mosaic of these units is a record of landscape, i.e. its resources. These resources are subject to evaluation providing the basis for the formulation of recomendations. Landscape may require conservation (activities aimed to keep a valuable unit in existing form), integration (in case of disturbed values but only to a limited extent), reconstruction (when valuable landscape has been devastated) or recomposition (developing suitable vicinity for units with outstanding values).

In the definitions formulated by landscape ecologists, elements of all the concepts discussed above can be found. The interest of landscape ecology lies in the structure of landscape and its spatial relationships (the type of research that is particularly well developed in geographical studies), variability and functioning of landscape (studied first of all by biological science and geochemistry), as well as physiognomic features of landscape (object of study in landscape architecture). For landscape ecologists, human beings, i.e. society, constitute an element of landscape, a view which is difficult to accept for some representatives of natural sciences.

Even in the places, where man rarely appears (the glacial and sandy deserts or high mountains), landscape is subject to anthropogenic impact. The areas inhabited by man are transformed to a definite extent or at least changed. Troll, the author of the term of "landscape ecology", defined landscape in 1939 as a whole comprising geosphere, biosphere and noosphere, that is - the sphere of mind. Schmithüsen (1949) distinguished in the diagram of interactions of the landscape elements the inorganic world, ruled by the physical causality, the organic world, subordinated to the laws of living matter, and the world of the "spirit", which is ruled by its own, specific laws. The landscape system is constructed, in accordance with this author, of the local abiotic complexes, biocenoses and human groups, constituting the wholes of a lower order, themselves composed, respectively, of abiotic elements and subsystems, biotic elements and individual persons. Naveh and Liebermann (1984) prove that landscape ecology developed in Central and Eastern Europe, since landscape in this region was viewed not only as an esthetic value and not only in terms of physical environment but as an entity within the man's living space, having proper spatial dimension, and the structural-functional as well as visual features.

Landscape as seen today is the spatial and material dimension earth reality and denotes a complex system composed of the forms of relief and waters, vegetation and soils, rocks and atmosphere (Zonneveld, 1990). Forman and Godron (1986) emphasize the fact that landscape constitutes a heterogenous fragment of the terrain composed of interrelated ecosystems and that landscapes are recurring in space in a similar form. In the opinion of Wieber (1987) the concept of landscape constitutes a fundamental idea in French 
geography. He thinks that efforts should now be made to treat landscape simultaneously in productive categories (studies of the landscape's potential) and in the categories of the manner of perceiving landscape (studies of landscape perception). Such an approach has in Wieber's opinion important social significance. According to Krzymowska-Kostrowicka (1993) each landscape forms a natural-cultural whole and constitutes the synthesis of four kinds of the space perceived: the permanent one (encompassing such components as relief, buildings, land use, etc.), the semi-permanent (changing during a year), the impermanent (episodic), and the space of interpersonal as well as interproductive contacts (distances).

The definitions introduced allow us to distinguish the following properties of landscape (see Zonneveld, 1990):

- landscape occupies a section of space and can be represented on a map;

- it is characterized by a certain physiognomy, which may be represented in a drawing or a photograph;

- it is a dynamic system functioning according to the given selection of its components, interactions between them and the nature of dominating processes;

- it is subject to evolution, i.e. has an own history.

Landscape definitions, especially those formulated by the representatives of landscape ecology, rarely determine its taxonomic rank, although it is widely accepted that landscape is a large spatial unit (Forman and Godron, 1986, write that the landscape diameter amounts to at least several kilometers), sometimes identified with a region (see Haber, 1987). In the taxonomy of physico-geographical units landscape is divided into smaller units, called by Russian geographers morphological parts of landscape. In the systems of vegetation classification the aspect of superiority of landscape is also emphasized. W. Matuszkiewicz (1974) uses the term of landscape to denote the structural-functional and dynamic ecological-spatial systems encompassing smaller and bigger segments of the biosphere and consisting of the groups of ecosystems interconnected by the definite biocenotic and biotopic relations.

It seems that regardless of the way of approaching the definition of landscape, discussed term is used to denote a "complete", though heterogenous whole functioning in accordance with the laws of nature, capable of selfregulating and marked with a certain individuality.

The delimitation of landscape units is conducted using a variety of methods. Therefore, it is difficult to compare the work of different authors, especially if they represent different schools. In methodology guidelines, one can find the statement that two basic approaches can be used: morphological and functional. The morphological approach defines the spatial extent of the unit, whereas the functional one outlines the change of states and processes occurring within the unit's limits. In reality, each spatial landscape unit is distinguished on the structural basis provided that the individual types of structure are characterised by a specific type of functioning. Understandably, 
each unit thus delimited could be characterized by a specific appearance and such appearance should constitute an important feature taken into account in the process of delimitation.

To sum up, one should emphasise the ambiguity of the notion of landscape and a certain margin of freedom in using it. Attempts at replacing the term with another word have not been successful, nor do they seem worthy of support. Despite the ambiguity of its definition, the landscape approach is commonly understood (also by non-specialists) as a holistic approach, normally related to the practical application of scientific research.

\section{REFERENCES}

Bogdanowski J., 1990, Metoda jednostek i wnętrz architektoniczno-krajobrazowych (JARKWAK) $w$ studiach $i$ projektowaniu [Method of landscape units and interiors (JARK-WAK) in studies and projects; in Polish], Politechnika Krakowska, Kraków.

Forman R.T.T., Godron M., 1986, Landscape Ecology, J. Wiley and Sons, New York.

H a b e r W., 1987, Using landscape ecology in planning and management, [in:] Zonneveld I.S., Forman R.T.T. (eds), Trends in Landscape Ecology, Springer Verlag.

Krzymowska-Kostrowicka A., 1993, Krajobraz jako przedmiot badań w ujęciu aksjologicznym [Landscape as an object of research in aksiological approach; in Polish], [in:] Pietrzak M. (ed.), Ekologia krajobrazu w badaniach terytorialnych systemów rekreacyjnych [Landscape-ecological studies on territorial recreational systems], Poznań.

Matuszkiewicz W., 1974, Teoretyczno-metodyczne podstawy badań roślinności jako elementu krajobrazu i obiektu użytkowania rekreacyjnego [Theoretical and methodological foundations of the study of vegetation as an element of landscape and object of recreational use; in Polish], Wiadomości Ekologiczne, 20, 1.

Naveh Z., Lieberman A., 1984, Landscape Ecology - Theory and Application, Springer Verlag, New York.

Schmithüsen J., 1964, "Was ist eine Landschaft?" Erdkundliches Wissen. Schriftenreihe für Forschung und Praxis, Heft 9.

Troll C., 1950, Die geographische Landschaft und ihre Erforschung - Studium Generale 3, Arbeiten aus dem Geogr. Inst. der Universitat Bonn.

Wieb e r J.C., 1987, Le paysage. Questions pour un bilan, Bull. Assoc. Géogr. Franc., Paris 2.

Z on neveld J.I.S., 1990, Introduction to "Cultural Aspects of Landscape", First Int. Conf. of the IALE Working Group "Culture and Landscape", (ed.) H. Svobodova, Wageningen. 